\title{
STABILITY ANALYSIS IN MAIZE (ZEA MAYS L.) FOR YIELD AND ITS COMPONENT CHARACTERS USING AMMI APPROACH
}

\author{
K. KUSELAN ${ }^{1}$, N. MANIVANNAN ${ }^{2}$, R. RAVIKESAVAN $^{3} \&$ V. PARANIDHARAN ${ }^{4}$ \\ ${ }^{I}$ Breeder(Maize), Rasi seeds Pvt Ltd. Attur Tamil Nadu, India \\ ${ }^{2}$ National pulses research center, TNAU, Vamban, Tamil Nadu, India \\ ${ }^{3}$ Department of millets, CPBG, TNAU, Coimbatore, Tamil Nadu, India \\ ${ }^{4}$ Department of plant pathology, TNAU, Coimbatore, Tamil Nadu, India
}

Forty five F1 hybrids evolved by half diallel mating, involving 10 inbreeds were used to estimate stability, for three yield related traits. The AMMI model, which had both additive and multiplicative effects, had been applied for the data. The analysis of variance for stability revealed that, the mean squares were significant for genotypes, environments, G $x$ E interactions, PCA I, PCA II, PCAIII and PCA IV, for all the three traits of interest. Among the genotypes, thirty four genotypes recorded significantly superior mean performance, for grain yield per plant over all environments. Among the high mean performing genotypes, six genotypes viz., RML27 x RML42, RML1 $x$ RML48, RML26 $x$ RML27, RML26 $x$ RML36, RML23 $x$ RML27 and RML12 $x$ RML23, recorded high interaction, twenty six genotypes, with the positive and negative type of interaction with the environment were noticed. Among the environments, E1 recorded low interaction. The environments $E 5$ and $E 6$ recorded positive type of interaction, while E3 and E1 recorded negative type of interaction. Among the genotypes, forty six genotypes recorded significantly, superior mean performance for grain yield per plot, in overall environments. Among the high mean performing genotypes, nine genotypes viz., RML36, RML1xRML48, RML36xRML37, RML23xRML27, RML1xRML23, RML26, RMLxRML26, RML12xRML23 and RML34xRML37 recorded high interaction, thirty genotypes with the positive and negative type of interaction, with the environment were noticed. Among the environments, E6 recorded high interaction. The environments E6 and E3, recorded positive type of interaction, while $\mathrm{E} 4$ recorded negative type of interaction.
\end{abstract}

KEYWORDS: Maize, Stability, AMMI Approach \& Grain Yield

Received: Jun 05, 2017;Accepted: Jul 12, 2017; Published: Jul 18, 2017; Paper Id.: IJASRAUG201736

\section{INTRODUCTION}

Maize is a highly cross pollinated crops and there is a wide scope, for exploitation of hybrid vigor. Already this phenomenon has been successfully exploited and still there is tremendous potential, to develop several high yielding hybrids and composites. Stability is the ability of a genotype, to have always the uniform yield regardless of environmental effects. Genotype x environment interaction ( $\mathrm{G} \times \mathrm{E})$, is a critical factor in crop improvement. Encountering the Gx E interaction in the study of genotype is a challenge to the plant breeders. A change in the environment may have greater effect in one genotype, than the other. The occurrence of $\mathrm{G} \times \mathrm{E}$ interaction has posed a major challenge, to a complete understanding of a genotype or hybrid. The location effect, seasonal fluctuation and their interaction highly, had its influence on the performance of genotypes, with its yield potential. Though maize hybrids are high yielders, the influence of $\mathrm{G} x \mathrm{E}$ interaction is more, on their performance. Hence, the developments of stable hybrids or lines, are the major objective of maize breeders. In maize, $\mathrm{G} \times \mathrm{E}$ 
interaction has been reported. Among different biomedical techniques used, to assess the $\mathrm{G} x \mathrm{E}$ interactions, the model like Principle Component Analysis (PCA) and linear regression are not adequate, in treating the complex data of yield trials effectively.

The AMMI model developed by Zobel et al. (1988), had both additive and multiplicative effects had been applied for the data. In an AMMI bi plot presentation, when a genotype and environment has the score sign on the PCAI axis interaction is positive, and if differ the interaction is negative. If a genotype or an environment has a PCAI score around zero, it has a small interaction effect and are considered as stable varieties, over a wide range of environments. However, genotypes with high mean and the high PCAI score are considered as having specifically adapted to the environments.

\section{MATERIAL AND METHODS}

The present study was carried out at the research and development center, Rasiseeds (P) Ltd., Attur, Tamil Nadu, during Rabi 2015 and kharif 2016, with three locations. The locations are: Kattukotai, Vadachennimalai and Bangalore, the pooled analysis was performed. Forty five F1 single cross hybrids, generated from half doll of 10 inbreed. The lines and their single cross hybrids, were tested at three locations both rabi and kharif seasons, along with the standard hybrid $\mathrm{CoH}(\mathrm{M}) 6$. The experiments were conducted in RBD, with two replications. The plots were $4 \mathrm{~m}$ length, each in two rows with a spacing of $60 \mathrm{~cm}$, between rows and $25 \mathrm{~cm}$ between plants. Recommended agronomic practices and need based plant protection measures were followed. The observations were recorded in each entry, in each replication and in each season, on five randomly selected plants, excluding border plants and their mean values were computed for statistical analysis, using TNAUSTAT and GENERES packages. The AMMI model developed had both additive and multiplicative effects had been applied to the data. In an AMMI bi plot presentation, when a genotype and environment, has the score sign on the PCAI axis, interaction is positive and if differs, the interaction is negative. If a genotype or an environment has a PCAI score around zero, it has a small interaction effect and are considered as stable varieties, over a wide range of environments. However, genotypes with high mean and the high PCAI score, are considered as having specifically adapted to the environments.

\section{RESULTS AND DISCUSSIONS}

The analysis of variance for stability revealed that, for all the characters, the mean squares were significant for genotypes, environments, G x E interactions, PCA I, PCA II, PCA III and PCAIV.(Table 1).

Estimates of stability, for the characters are furnished, in Table 2.

\section{Stability Analysis for Grain Yield and its Components}

Genotypes interaction with the environment and breeders usually apply some type of stability analysis, to determine the nature of interaction. A number of different approaches to stability analysis, have been developed to determine the response of hybrids, under different environmental conditions. The 45 hybrids evolved by half dialed mating involving 10 inbreeds were used to estimate stability for 3 yield related traits viz., hundred grain weight, grain yield per plant and grain yield per plot.

\section{Hundred Grain Weight}

Among the genotypes, nine genotypes recorded significantly superior mean four hundred grain weights than the check. Among these genotypes, four recorded low interaction with the environment. Eight genotypes recorded positive and 
negative type of interaction with the environment. Among the environments, E1 recorded low interactions. Two environments viz. E5 and E6 recorded positive type of interaction and E1 and E2 recorded negative type of interaction. Based on mean and PCA values, the genotypes viz. RML12 x RML27, RML23 x RML48, RML26 x RML34 and RML1 x RML26 were considered as stable genotypes for hundred grain weight.

\section{Grain Yield Per Plant}

Among the genotypes, thirty four genotypes recorded significantly superior mean performance for grain yield per plant in overall environments. Among the high mean performing genotypes, six genotypes viz., RML27 x RML42, RML1 x RML48, RML26 x RML27, RML26 x RML36, RML23 x RML27 and RML12 x RML23 recorded high interaction and twenty six genotypes with the positive and negative type of interaction with the environment were noticed. Among the environments, E1 recorded low interaction. The environments E5 and E6 recorded positive type of interaction, while E3 and E1 recorded negative type of interaction. (Table 2 and Figure 1).

\section{Grain Yield per Plot}

Among the genotypes, forty six genotypes recorded significantly superior mean performance for grain yield per plot in overall environments. Among the high mean performing genotypes, nine genotypes viz., RML36, RML1xRML48, RML36xRML37, RML23xRML27, RML1xRML23, RML26, RMLxRML26, RML12xRML23 and RML34xRML37 recorded high interaction; thirty genotypes with the positive and negative type of interaction with the environment were noticed. Among the environments, E6 recorded high interaction. The environments E6 and E3 recorded positive type of interaction, while E4 recorded negative type of interaction (Table 2 and Figure 1).

\section{CONCLUSIONS}

Stability analysis for grain, yields indicated that, hybrids viz., RML27 x RML42, RML1 x RML48, RML26 x RML27, RML26 x RML36, RML23 x RML27 and RML12 x RML23, were stable in performance over the environments. The hybrid RML1 x RML48 and RML23 x RML27, were also found to be stable for grain yield, per plant apart from grain yield per plot. The selected hybrids exhibited higher mean performance and positive interaction. The largest number of locations are necessary, to obtain reliable estimates of stability of a hybrid. Breeder's first select high yielding hybrids and as more data becomes available, select the most stable hybrids, from among those with high yield.

\section{REFERENCES}

1. Becker, H.C. and Leon, J.1988.Stability analysis in plant breeding. Plant breeding.101:1-23.

2. Eberhart, S.A. and Russel, W.L. (1996).Stability parameters for comparing varieties. Crop sci., 6:36-40.

3. Finley K.W. and Wilkinson G.N. 1963. The analysis of adaptation in a plant breeding programme. Aust. J. Agric. Res., 14: 742-754.

4. Gama E.E.G.E. and Hallauer A.R.1980.Stability of hybrids reduced from selected and unselected lines of maize. Crop Sci., 20: 623-626.

5. Helms T.C. 1993. Selection for yield and stability among oat lines. Crop Sci., 30 : 423426

6. Holland J.B., Bjonstad A., and Frey K.J., Gullord M. and Wesenberg D.M.. 2002. Recurrent selection for broad adaptation affects stability of oat. Euphytica, $126: 265-274$. 
7. Jensen S.D. and Cavalieri A.J. 1983. Drought tolerance in US maize. Agric. Water Mgt., 7 : 223-236

8. Lata S. Guloria., Jai Dev., Katna G., Sood C., Kalia V. and An and Singh. 2010. Stability analysis of maize (Zea mays L.) hybrids across loctors. Electronic J.of plant breeding 1 : 239-243.

9. Ogunbodede B.A., Ajibade S. R. and Olakojo S.A. 2001.Grain yield stability of new maize varieties in Nigeria. Agrican Crop Sci. J., 9: 685-691.

10. Sain doss.1991, Stability analysis in maize. Crop Res., 14:185-187.

11. Suthamathi. P and Nallathambi.G.2016.AMMI approach for grain yield and stability of maize (Zea mays L.). Electronic J. plant breeding 1: 0975-928X.

12. Zobel R.W., Wright and Gauch H.G. 1988.Statistical analysis of a yield trial Agron. J., 80: 388-393.

\section{APPENDICES}

Table 1: Analysis of Variances for Stability analysis (AMMI Model)

\begin{tabular}{|l|c|c|c|c|}
\hline \multicolumn{1}{|c|}{ Sources } & DF & $\begin{array}{c}\text { Hundred Grain } \\
\text { Weight }\end{array}$ & $\begin{array}{c}\text { Grain Yield Per } \\
\text { Plant }\end{array}$ & $\begin{array}{c}\text { Grain Yield per } \\
\text { Plot }\end{array}$ \\
\hline Genotypes & 55 & $74.77^{* *}$ & $8259.41^{* *}$ & $10.84^{* *}$ \\
\hline Environments & 5 & $970.29^{* *}$ & $148881.00^{* *}$ & $176.48^{* *}$ \\
\hline G X E interaction & 275 & $6.30^{* *}$ & $570.18^{* *}$ & $0.91^{* *}$ \\
\hline PCA I & 59 & $9.40^{* *}$ & $1123.05^{* *}$ & $2.30^{* *}$ \\
\hline PCA II & 57 & $7.21^{* *}$ & $527.26^{* *}$ & $0.67 * *$ \\
\hline PCA III & 55 & $6.26^{* *}$ & $506.85^{* *}$ & $0.55^{* *}$ \\
\hline PCA IV & 53 & $5.32^{* *}$ & $369.98^{* *}$ & $0.54 * *$ \\
\hline Error & 335 & 10696.70 & 1355470.00 & 1727.89 \\
\hline
\end{tabular}

$*_{\text {-Significant at } 1 \% \text { level }}$

Table 2: Estimates of Stability Analysis (AMMI Model) for Hundred Grain Weight, Grain Yield per Plant and Grain Yield per Plot

\begin{tabular}{|c|c|c|c|c|c|c|c|c|c|c|}
\hline \multirow{2}{*}{$\begin{array}{l}\text { SL. } \\
\text { No. }\end{array}$} & \multirow[t]{2}{*}{ Genotypes } & \multicolumn{3}{|c|}{$\begin{array}{l}\text { Hundred Grain } \\
\text { Weight (gm) }\end{array}$} & \multicolumn{3}{|c|}{$\begin{array}{c}\text { Grain Yield per Plant } \\
\text { (gm) }\end{array}$} & \multicolumn{3}{|c|}{ Grain Yield Per Plot(kg) } \\
\hline & & Mean & PCA I & PCA II & Mean & PCA I & PCA II & Mean & PCA I & PCA II \\
\hline 1 & RML1xRML12 & 31.46 & 0.90 & 0.84 & 76.12 & -1.23 & -0.43 & 2.42 & -0.08 & 0.19 \\
\hline 2 & RML1xRML23 & 33.04 & 0.95 & 0.10 & 162.73 & -1.09 & 1.23 & 5.91 & 0.84 & -0.25 \\
\hline 3 & RML1xRML26 & 37.17 & 0.45 & 0.86 & 163.09 & -1.14 & -1.84 & 5.42 & 0.22 & -0.03 \\
\hline 4 & RML1xRML27 & 33.83 & 0.60 & 0.99 & 163.98 & 4.43 & 3.14 & 5.59 & -0.67 & -0.32 \\
\hline 5 & RML1xRML34 & 36.54 & -0.62 & 0.07 & 163.18 & -1.52 & -1.25 & 5.26 & 0.20 & 0.06 \\
\hline 6 & RML1xRML36 & 30.25 & 0.43 & -0.11 & 147.55 & -2.65 & 0.99 & 4.96 & 0.23 & 0.39 \\
\hline 7 & RML1xRML37 & 32.29 & 0.74 & -0.43 & 140.12 & -4.89 & 3.77 & 5.22 & 1.05 & 0.24 \\
\hline 8 & RML1xRML42 & 33.21 & -0.30 & 0.81 & 134.28 & -1.60 & 3.14 & 5.16 & 1.11 & 0.10 \\
\hline 9 & RML1xRML48 & 36.12 & -0.31 & 0.05 & 180.88 & 0.12 & -0.71 & 6.32 & 0.32 & -0.36 \\
\hline 10 & RML12xRML23 & 30.75 & 0.42 & 0.33 & 178.10 & 1.27 & 1.80 & 5.83 & 0.10 & 0.11 \\
\hline 11 & RML12xRML26 & 28.21 & 1.06 & -0.48 & 67.45 & -0.44 & 1.50 & 1.98 & -0.21 & 0.13 \\
\hline 12 & RML12xRML27 & 39.88 & 1.25 & 0.98 & 161.78 & -2.78 & -0.59 & 5.15 & 0.30 & 0.40 \\
\hline 13 & RML12xRML34 & 27.04 & -0.06 & -0.37 & 153.42 & -2.13 & 1.46 & 5.23 & 0.40 & 0.12 \\
\hline 14 & RML12xRML36 & 32.29 & 0.30 & 0.36 & 150.08 & 0.16 & 0.35 & 4.87 & 0.18 & -0.04 \\
\hline 15 & RML12xRML37 & 29.92 & -0.57 & 0.35 & 158.15 & -1.24 & -1.65 & 5.06 & -0.04 & 0.07 \\
\hline 16 & RML12xRML42 & 29.75 & -0.38 & 0.20 & 132.26 & -2.91 & -0.57 & 4.48 & 0.51 & 0.26 \\
\hline 17 & RML12xRML48 & 33.29 & 0.19 & 0.43 & 153.94 & -0.65 & -0.69 & 5.16 & 0.29 & -0.16 \\
\hline 18 & RML23xRML26 & 33.79 & -0.45 & 0.26 & 172.32 & 0.18 & -0.39 & 5.85 & 0.13 & -0.07 \\
\hline 19 & RML23xRML27 & 32.71 & 0.39 & -0.05 & 180.68 & 0.85 & -0.68 & 6.09 & 0.07 & -0.20 \\
\hline 20 & RML23xRML34 & 29.65 & 0.82 & -1.01 & 70.48 & 3.35 & 1.32 & 1.66 & -0.78 & 0.42 \\
\hline 21 & RML23xRML36 & 34.62 & 0.71 & 0.24 & 154.85 & -2.01 & -2.33 & 4.97 & 0.55 & 0.19 \\
\hline
\end{tabular}




\begin{tabular}{|c|c|c|c|c|c|c|c|c|c|c|}
\hline \multicolumn{11}{|c|}{ Table 2: Contd., } \\
\hline 22 & RML23xRML37 & 37.12 & 0.60 & -0.12 & 161.22 & -0.96 & -2.24 & 5.02 & 0.37 & -0.22 \\
\hline 23 & RML23xRML42 & 36.71 & 0.40 & 0.38 & 171.54 & 1.49 & -0.97 & 5.25 & -0.11 & 0.04 \\
\hline 24 & RML23xRML48 & 38.00 & 0.15 & 0.78 & 173.12 & -1.33 & -2.47 & 5.37 & 0.10 & -0.17 \\
\hline 25 & RML26xRML27 & 35.04 & -0.65 & -0.36 & 180.81 & 4.55 & -3.81 & 5.63 & -0.19 & -1.16 \\
\hline 26 & RML26xRML34 & 37.71 & 0.46 & 0.86 & 164.09 & 1.27 & -1.98 & 4.86 & 0.01 & -0.27 \\
\hline 27 & RML26xRML36 & 35.00 & 0.84 & -0.19 & 180.70 & 0.52 & -3.94 & 5.61 & -0.16 & -0.13 \\
\hline 28 & RML26xRML37 & 26.12 & 0.00 & -0.33 & 75.47 & 0.47 & 1.63 & 2.58 & -0.11 & 0.14 \\
\hline 29 & RML26xRML42 & 30.25 & 0.50 & -0.13 & 127.58 & -1.10 & 2.39 & 4.49 & 0.24 & 0.33 \\
\hline 30 & RML26xRML48 & 25.00 & -0.10 & -0.59 & 161.06 & 1.12 & 2.37 & 5.54 & -0.19 & 0.04 \\
\hline 31 & RML27xRML34 & 28.58 & -0.41 & 0.04 & 154.29 & 1.06 & 1.62 & 5.43 & 0.26 & -0.36 \\
\hline 32 & RML27xRML36 & 32.21 & -0.82 & 0.06 & 112.82 & 0.37 & -0.52 & 3.62 & -0.09 & -0.01 \\
\hline 33 & RML27xRML37 & 31.29 & 0.09 & -0.14 & 146.28 & -0.15 & 0.42 & 4.76 & 0.09 & 0.14 \\
\hline 34 & RML27xRML42 & 27.67 & 0.13 & -0.70 & 186.51 & 2.98 & 2.58 & 6.60 & -0.09 & -0.38 \\
\hline 35 & RML27xRML48 & 29.92 & -0.86 & -0.53 & 91.00 & -0.34 & 2.57 & 2.86 & -0.35 & 0.36 \\
\hline 36 & RML34xRML36 & 30.25 & -0.96 & -0.40 & 159.51 & -0.43 & -0.51 & 5.17 & 0.07 & -0.28 \\
\hline 37 & RML34xRML37 & 31.83 & 0.17 & -0.78 & 172.49 & -2.22 & 1.29 & 5.81 & 0.35 & 0.00 \\
\hline 38 & RML34xRML42 & 34.17 & -0.39 & -0.21 & 112.49 & -0.29 & $\begin{array}{c}-0.14 \\
\end{array}$ & 3.56 & -0.04 & 0.20 \\
\hline 39 & RML34xRML48 & 36.42 & -1.07 & 0.35 & 169.49 & -0.53 & -2.18 & 5.38 & -0.17 & -0.26 \\
\hline 40 & RML36xRML37 & 32.54 & -0.06 & 0.31 & 191.84 & -1.23 & -1.58 & 6.19 & 0.15 & -0.04 \\
\hline 41 & RML36xRML42 & 26.17 & -0.15 & -1.97 & 77.96 & -1.15 & $\begin{array}{c}-0.39 \\
\end{array}$ & 2.36 & -0.11 & 0.03 \\
\hline 42 & RML36xRML48 & 29.08 & 0.00 & -0.58 & 141.68 & 0.73 & 0.72 & 4.49 & -0.35 & -0.03 \\
\hline 43 & RML37xRML42 & 30.92 & -0.99 & -0.41 & 167.23 & 0.11 & -0.64 & 5.47 & -0.21 & 0.01 \\
\hline 44 & RML37xRML48 & 31.17 & -0.33 & -0.56 & 163.83 & -0.83 & -2.28 & 5.47 & 0.08 & -0.33 \\
\hline 45 & RML42xRML48 & 30.17 & -0.30 & -0.24 & 163.15 & 0.97 & -1.56 & 5.15 & -0.47 & -0.02 \\
\hline 46 & RML1 & 27.88 & 0.67 & 0.22 & 89.79 & 9.82 & -0.72 & 2.85 & -1.35 & -1.04 \\
\hline 47 & RML12 & 31.42 & -1.11 & 1.72 & 153.76 & 1.20 & -0.96 & 4.82 & -0.49 & -0.21 \\
\hline 48 & RML23 & 34.08 & 0.28 & 0.13 & 160.90 & -1.03 & 1.48 & 5.61 & 0.49 & 0.12 \\
\hline 49 & RML26 & 31.21 & 0.61 & -0.54 & 171.23 & 0.56 & 1.67 & 5.86 & 0.20 & -0.17 \\
\hline 50 & RML27 & 36.42 & -1.27 & -0.50 & 77.51 & 0.14 & -0.19 & 2.11 & -0.34 & 0.31 \\
\hline 51 & RML34 & 35.79 & -1.32 & 0.54 & 141.08 & -1.70 & -1.23 & 4.44 & 0.20 & 0.25 \\
\hline 52 & RML36 & 35.62 & -0.09 & 0.11 & 194.32 & 0.45 & -0.83 & 6.42 & 0.14 & -0.11 \\
\hline 53 & RML37 & 30.04 & 0.16 & -0.38 & 57.64 & 0.34 & -0.56 & 1.54 & -0.46 & 0.13 \\
\hline 54 & RML42 & 34.29 & -0.33 & 0.68 & 172.10 & -1.48 & -1.64 & 5.33 & -0.20 & 0.42 \\
\hline 55 & RML48 & 24.17 & 0.85 & -0.85 & 62.48 & 1.64 & 2.15 & 1.74 & -0.66 & 0.38 \\
\hline & Check & 35.58 & -1.18 & -0.11 & 152.08 & 0.15 & 1.70 & 3.16 & -1.40 & 1.01 \\
\hline & Mean E1 & 26.36 & 0.24 & -3.81 & 100.25 & -2.35 & 1.32 & 3.36 & -0.33 & 0.36 \\
\hline & Mean E2 & 28.79 & 0.72 & -0.60 & 126.28 & -2.66 & 2.50 & 4.24 & 0.01 & 0.45 \\
\hline & Mean E3 & 32.30 & -2.58 & 0.88 & 221.22 & -6.92 & -10.01 & 7.28 & 2.64 & -0.96 \\
\hline & Mean E4 & 32.58 & 2.71 & 1.08 & 110.15 & 13.19 & $\begin{array}{l}-2.39 \\
\end{array}$ & 3.29 & -1.85 & -1.76 \\
\hline & Mean E5 & 36.71 & 1.50 & 1.72 & 112.17 & 2.71 & 0.91 & 3.45 & -0.96 & 1.07 \\
\hline & Mean E6 & 36.72 & -2.60 & 0.72 & 198.28 & -3.97 & 7.66 & 6.58 & 0.49 & 0.85 \\
\hline & Grand mean & 32.24 & 0.00 & 0.00 & 144.70 & 0.00 & 0.00 & 4.70 & 0.00 & 0.00 \\
\hline & $\mathrm{CD}$ at $5 \%$ & 2.02 & & & 18.23 & & & 0.59 & & \\
\hline
\end{tabular}




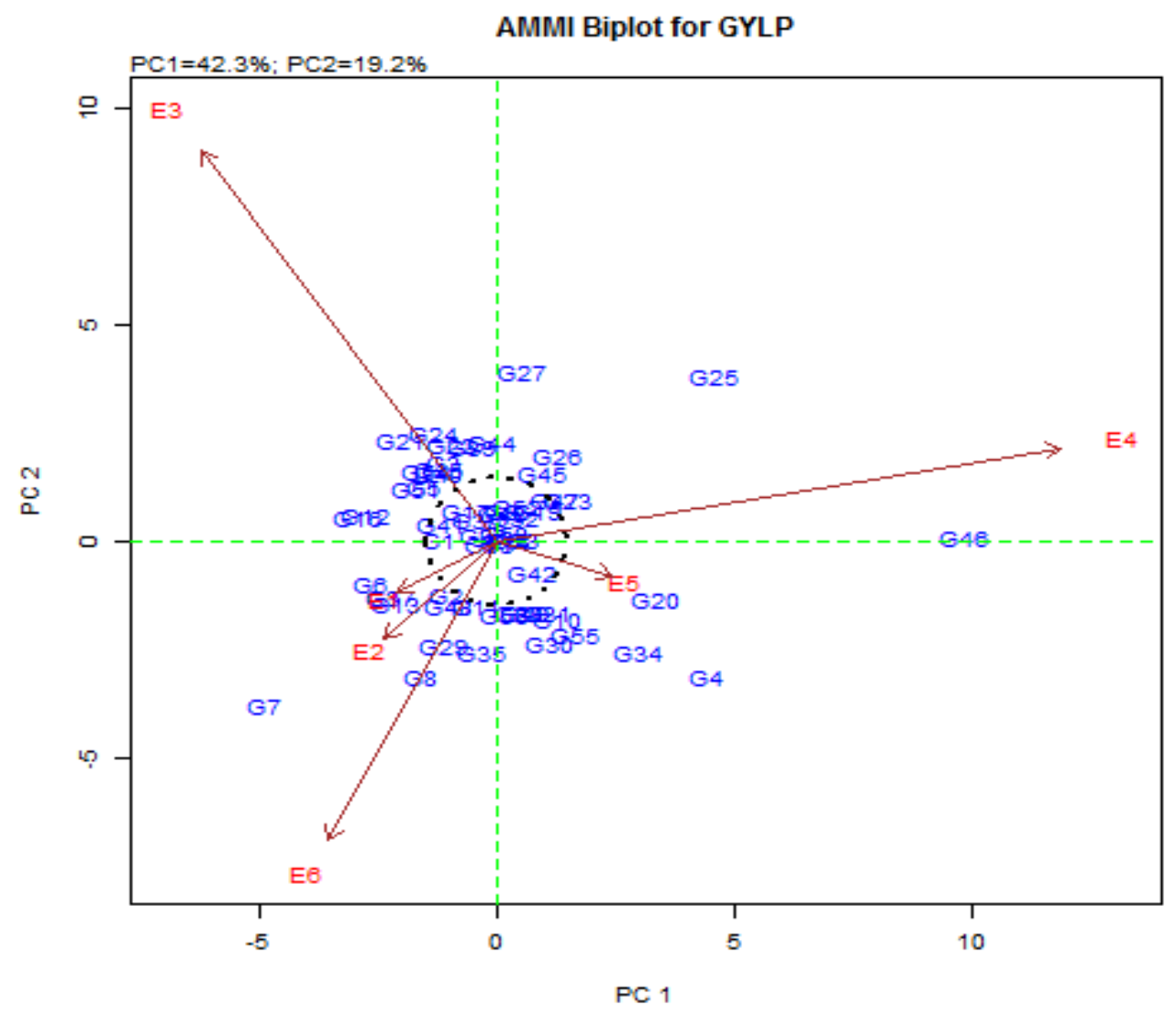

Figure 1: Biplot Graph for Mean, PCA I and PCA II-Grain Yield per Plant 